\title{
HUMAN PAPILLOMAVIRUS GENOTYPES IN WOMEN WITH CERVICAL CYTOLOGICAL ABNORMALITIES FROM AN AREA WITH HIGH INCIDENCE OF CERVICAL CANCER
}

\author{
Gerardo Daniel DELUCA(1), Raúl Horacio LUCERO(1), María T. MARTIN de CIVETTA(2), Lilian VICENTE(3), Ofelia L.Z. de GORODNER(4),
} Eduardo SCHELOVER(4) \& José Mario ALONSO(1)

\begin{abstract}
SUMMARY
It has been well demonstrated the relationship between the infection with high-risk human papillomavirus (HPVs) genotypes and cervical cancer. In Northeastern Argentina a high incidence of this pathology has been described and therefore a high prevalence of HPV infection is expected. In order to identify HPV genotypes associated with malignant and pre-malignant cervical lesions present in the area, 53 ecto-endo cervical cell specimens obtained from women with cytohistological alterations were studied by a PCR-RFLP technique. Out of 53 patients, $34(64.2 \%)$ were positive for HPV infection, being HPV-16 (32.3\%) the most frequently found genotype, followed by HPV-58 (14.7\%), -6, -18 and -45 (5.9\%), -33, -52, -53, -54, -56, -66, -MM4 and -LVX100 (2.9\%). Also 5 cases of infection caused by multiple genotypes were found, which corresponded to $14.7 \%$ of the positive cases. Results indicate that besides HPV-16 and -18, the most prevalent high-risk HPV genotypes worldwide, others like -45 and -58 as well as co-infection cases are frequent between women of Northeastern Argentina, and a particular attention should be paid to this circumstance because it could be an epidemiological feature of regional importance and a useful information for a future vaccination program.
\end{abstract}

KEYWORDS: HPV; Cervical cancer; Papillomavirus; PCR-RFLP.

\section{INTRODUCTION}

Human papillomavirus (HPVs) are natural occurring DNA tumor viruses which induce epithelial proliferation during the course of a productive infection and are known to be consistently associated with cervical cancer ${ }^{18,31}$.

Human papillomavirus invade epithelium germinal cells through microlesions and the resulting infection may be transient or persistent ${ }^{4,10,27}$.

Even though infection with oncogenic HPV genotypes is frequent among sexually active women, most of the cases are autolimited ${ }^{28}$; the development of malignant cervical lesions only occurs in a small proportion of infected women that harbor persistent infections with oncogenic genotypes ${ }^{9,17,26}$. It has been demonstrated the integration of viral genome within malignant cells in all cervical cancer cases, which is thought to be a necessary condition for the development of neoplasia ${ }^{11,12,21}$.

More than $80 \mathrm{HPV}$ genotypes have been identified up to the present days, and about 40 of them infect the anogenital region. Within the anogenital genotypes, HPV-16, -18,- 31, -33, -35, -39, -45, -51, -52, $-56,-58,-59,-68,-73$, and -82 were classified as high-risk group, because they were clearly identified in patients with malignant cervical lesions ${ }^{16,24}$.
Uterine cervical cancer is the second most common type of cancer among women worldwide, but in Latin America the prevalence rates are about 4 fold higher than in USA and in other developed countries ${ }^{6}$.

Although available epidemiological information about this disease is somehow scarce in Argentina, data show a significant variation in the mortality rates for the different regions of the country; from 7 cases out of 100,000 women in the metropolitan area of Buenos Aires city to 1722 cases out of 100,000 women in Northeast Argentina ${ }^{15}$. In spite of this feature, few epidemiological studies were performed in this last region related to HPV infection and they exclusively focused on a limited number of genotypes, mainly $-6,-11,-16$ and $-18^{30}$. For these reasons we considered relevant to investigate the presence of other genotypes also associated with cervical malignancy. The aim of this work was to evaluate the presence of HPV genotypes infecting sexually active adult women with cervical abnormalities, and correlate genotypes with the cytohistological type of lesions.

\section{MATERIALS AND METHODS}

Subjects: All women self-referring for gynecological examination at the Gynecology Service of "J.R.Vidal Hospital" in Corrientes city and at a private gynecological clinic in Resistencia city, were enrolled in a HPV study from August 2001 to August 2002. A routine gynecological examination including colposcopy was completed, and exfoliated cervical

(1) Area de Biología Molecular. Instituto de Medicina Regional. Universidad Nacional del Nordeste. Resistencia, Argentina

(2) Servicio de Ginecología. Hospital “J. R. Vidal”. Corrientes, Argentina.

(3) Instituto Médico 9 de Julio. Resistencia, Argentina.

(4) Servicio de Anatomía Patológica. Hospital "J. R. Vidal". Corrientes, Argentina.

Correspondence to: Gerardo D. Deluca, Instituto de Medicina Regional, Av. Las Heras 727, (3500), Resistencia, Argentina. Fax: 54-3722-422793. E-mail: gerdeluca@ hotmail.com 


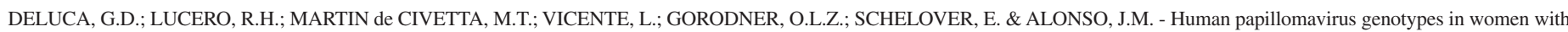
cervical cytological abnormalities from an area with high incidence of cervical cancer. Rev. Inst. Med. trop. S. Paulo, 46(1):9-12, 2004.

cells were taken for PAP smear. Within the next 30 days, patients who presented any cytohistological lesion, excluding inflammatory PAP smears, were called again and asked for authorization for a new cervical cell sampling to evaluate HPV infection. Upon this procedure, 53 women were studied belonging to the following groups: 3 women with atypical squamous cells of undetermined significance (ASCUS), 36 with lowgrade cervical intraepithelial lesions (L-SIL), 5 with high-grade cervical intraepithelial lesions (H-SIL) and 9 with uterine cervical cancer in different stages.

PCR for HPV detection: For viral analysis, cell samples were collected by scraping the uterine ecto-endo cervix with a cytobrush. Cells were washed in sterile buffered saline and the final cellular pellet was kept at $-70{ }^{\circ} \mathrm{C}$ until DNA extraction.

DNA was obtained by treating the pellet with $400-700 \mu$ of homogenization solution ( $2 \%$ cetyltrimethylammonium bromide-CTAB, $1.4 \mathrm{M} \mathrm{NaCl}, 0.2 \% \beta$-mercaptoethanol, $20 \mathrm{mM}$ EDTA, $100 \mathrm{mM}$ Tris$\mathrm{HCl} \mathrm{pH} 5.0$ ), extracted with phenol:chlorophorm:isoamyl alcohol method, then precipitated with ethanol and resuspended in 50-100 $\mu \mathrm{l}$ bidestilled sterile water. All samples were tested for quality and integrity of DNA by PCR with the use of exon III from the human B-actin gene that produces a $289 \mathrm{bp}$ amplimer. Samples negative for this primer were considered unadequate and discarded.

PCR was performed in a reaction mixture of $100 \mu \mathrm{l}$ containing $10 \mathrm{mM}$ Tris- $\mathrm{HCl} \mathrm{pH} \mathrm{8.3,} 50 \mathrm{mM} \mathrm{KCl}, 2.5 \mathrm{mM} \mathrm{Mg} \mathrm{Cl}, 0.2 \mathrm{mM}$ of each dNTP (Promega Inc. - USA), 0.5 Units of Taq DNA polymerase (Promega Inc. - USA), $0.5 \mathrm{mM}$ of generic primers MY09 and MY11 (Cyber-Sin, USA), and $5 \mu$ of sample purified DNA. Each PCR was carried out in a DNA thermal cycler (MJ Research Inc., PTC-150), with first denaturation step at $94{ }^{\circ} \mathrm{C}$ for $4 \mathrm{~min}$ and final extension step at $72{ }^{\circ} \mathrm{C}$ for $5 \mathrm{~min}$. DNA amplification was performed during 35 cycles which included the denaturation at $94{ }^{\circ} \mathrm{C}$ for $60 \mathrm{~s}$, the annealing at $52{ }^{\circ} \mathrm{C}$ for $60 \mathrm{~s}$, and the primer extension at $72{ }^{\circ} \mathrm{C}$ for $60 \mathrm{~s}$. To avoid false negatives and false positives a reagent control (no template DNA) and known HPV DNA from infected HPV-16 CasKi cells were included in each amplification. PCR product was electrophoresed on $3 \%$ agarose gel, stained with ethidium bromide, and photographed under UV light.

Restriction digestion, RFLP analysis: Positive samples products were digested as described by BERNARD et al. ${ }^{3}$, with 8-10 Units of each one of the following enzymes: Bam HI, Dde I, Hae III, Hinf I, Pst I, Rsa I and Sau3AI (Promega, USA). The digested products were electrophoresed on $3 \%$ agarose gel, stained with ethidium bromide and photographed under UV light. Restriction fragment length polymorphism (RFLP) patterns were analyzed and compared with published data ${ }^{3}$.

\section{RESULTS}

Out of the 53 samples analyzed, 34 (64\%) were positive for HPVDNA. Its distribution according to the type of cytohistological lesions is referred in Table 1.

In regard to the genotypification, HPV infecting types could be identified in $26 / 34$ positive samples. From the 8 remaining samples, the identification could not be resolved in 5 cases due to the fact that they showed a very weak restriction pattern with a blurred image unable for a distinct viral identification; 2 showed restriction maps which did not correspond to none of the patterns described by BERNARD et al. ${ }^{3}$, and the last one was a case of mixed infection with a very complicated restriction pattern that could not be elucidated (Table 2).

Table 1

PCR for HPV-DNA in women with uterine cervical lesions

\begin{tabular}{lccccc}
\hline & ASCUS & L-SIL & H-SIL & $\begin{array}{c}\text { Cervical } \\
\text { cancer }\end{array}$ & Total \\
\hline Positive & 2 & 19 & 4 & 9 & 34 \\
Negative & 1 & 17 & 1 & - & 19 \\
Total & 3 & 36 & 5 & 9 & 53 \\
\hline
\end{tabular}

Table 2

Distribution of HPV genotypes according to histopathological cervical lesions, in 34 HPV-DNA positive samples

\begin{tabular}{lccccr}
\hline Genotype & $\begin{array}{c}\text { ASCUS } \\
\mathrm{n}=3\end{array}$ & $\begin{array}{c}\text { L-SIL } \\
\mathrm{n}=36\end{array}$ & $\begin{array}{c}\mathrm{H}-\mathrm{SIL} \\
\mathrm{n}=5\end{array}$ & $\begin{array}{c}\text { Cervical } \\
\text { cancer } \mathrm{n}=9\end{array}$ & $\begin{array}{c}\text { Total } \\
(\%)\end{array}$ \\
\hline 6 & & 2 & & & $2(5.9)$ \\
16 & & 3 & 3 & 5 & $11(32.3)$ \\
18 & & 2 & & & $2(5.9)$ \\
33 & & 1 & & & $1(2.9)$ \\
45 & & 1 & & 1 & $2(5.9)$ \\
52 & & 1 & & & $1(2.9)$ \\
53 & & 1 & & & $1(2.9)$ \\
54 & & 1 & & & $1(2.9)$ \\
56 & & 1 & & & $1(2.9)$ \\
58 & & 2 & 1 & 2 & $5(14.7)$ \\
66 & & 1 & & & $1(2.9)$ \\
MM4 & 1 & & & & $1(2.9)$ \\
LVX100 & 1 & 3 & & 1 & $5(14.7)$ \\
Not identified* & & 2 & 1 & & $3(8.8)$ \\
Undetermined & & & & &
\end{tabular}

* RFLP not done

Out of the 34 positive samples, $5(14.7 \%)$ were multiple infection cases produced by more than one viral genotype. In 4 of them final genotyping could be successfully resolved by RFLP: HPV-58/45, HPV6/33, HPV-16/58, HPV-16/66, remaining one case undetermined.

\section{DISCUSSION}

Recent advances in molecular techniques allowed the use of highly sensitive methodologies for the detection of HPV-DNA, such as filter in situ hybridization (FISH), southern hybridization (SH), Hybrid Capture tm $^{\text {tm }}$ (HC) and the polymerase chain reaction (PCR), being the latter one of the most frequently employed ${ }^{2,7,13}$. However, these methodologies for virological diagnosis do not replace classical gynecological exploration techniques for cytohistological disturbances (PAP, colposcopy and biopsies), but rather, they complement them ${ }^{22,25}$.

The high incidence of HPV infection previously reported in the Northern region of Argentina ${ }^{20,30}$ is consistent with a high incidence of uterine cervix cancer present in the area. In this work, only patients with cytohistological 


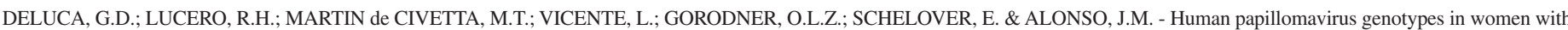
cervical cytological abnormalities from an area with high incidence of cervical cancer. Rev. Inst. Med. trop. S. Paulo, 46(1):9-12, 2004.

alterations and colposcopy compatible with HPV infection were studied. As expected, we certainly found a high frequency of HPV infection, particularly among H-SIL and cancer cases, while in the L-SIL group virus DNA was found only in $52 \%$ of the cases. This percentage may be regarded as low if compared with the findings of authors who referred infection rates as high as $70 \%{ }^{8}$. Nevertheless, in other reports the presence of viral DNA in this type of patients is considered uncertain ${ }^{23}$. Our results could be directly related to the number of cases analyzed and a better estimation could be probably reached studying a greater number of L-SILs .

The PCR-RFLP technique employing MY generic primers allows the recognition of more than 30 genital genotypes in a single amplification reaction ${ }^{3}$. This is its major advantage in comparison to other methodologies that use specific primers, but its disadvantage is just not to be able to define certain cases of infection caused by multiple genotypes, which frequently produce blurred restriction patterns ${ }^{1}$. In such cases final identification may be achieved by PCR with subsequent DotBlot hybridization, by PCR with specific primers, or by nucleotide sequence analysis ${ }^{1,5,29}$.

In this work, RFLP analysis could not be performed in five positive samples because genomic material did not amplify enough to obtain a definite pattern with clear-cut bands. We suppose these cases may belong to those whose initial viral genomic load stands on the limit of the technique's threshold ${ }^{14}$. Also, two samples showed patterns that could not be associated with any of the genotypes described by the methodology employed; therefore, it would be necessary to perform DNA sequence analysis to assess if they correspond to intratypic variations, subtypes or to novel genotypes ${ }^{19}$.

In agreement with the reports of other epidemiological surveys ${ }^{20,30}$, HPV-16 was the most frequent genotype in our series, but HPV-58 was in the second place instead of HPV-18, $-31,-33$ and -45 as in the most of the series. However, geographical variations in the occurrence of the HPV genotypes are well known and depends on the epidemiological features of each region ${ }^{24}$.

The knowledge of the most prevalent HPV genotypes present in a region with a high incidence of cervical cancer is relevant in order to design an effective HPV nationwide vaccination program. In this way, our research may be a contribution for a better knowledge of the problem in an area without many data on HPV infection.

We may conclude that in Northeastern Argentina, an important number of high-risk HPV genotypes are circulating, and the results of this study show that besides HPV-16 and HPV-18, other types like HPV58 are also frequent, as well as infections produced by more than one genotype. Attention should be focussed on these circumstances since they could be of local epidemiological significance.

\section{RESUMEN}

\section{Genotipos de virus papiloma humano en mujeres con alteraciones citológicas cervicales de un área con alta incidencia de cáncer cervical}

La relación entre la infección por los virus papiloma humanos (HPVs) de alto riesgo y el cáncer de cuello de útero ha sido bien demostrada. En el Nordeste de Argentina se observa una alta incidencia de esta patología y en consecuencia se estima una alta prevalencia de infección por HPV. A fin de identificar los genotipos de HPV presentes en el área, asociados a casos de lesiones malignas y premalignas de cuello de útero, se estudiaron 53 muestras ecto-endo cervicales de mujeres con alteraciones citohistológicas residentes permanentes de las ciudades de Resistencia y Corrientes. De las 53 pacientes estudiadas, 34 resultaron positivas para HPV (64.2\%), correspondiendo la mayor frecuencia a HPV-16 (32.3\%), seguido por HPV-58 (14.7\%), HPV-6, -18 y -45 (5.9\%), -33, -52, -53, -54, -56, -66, -MM4 y -LVX100 (2.9\%). Además, se encontraron 5 casos de infecciones mixtas causadas por mas de un genotipo, lo que resulta de importancia ya que representan el $14.7 \%$ del total de los casos positivos. Los resultados demuestran que, además de HPV-16 y -18 que son los genotipos de alto riesgo de mayor prevalencia a nivel mundial, otros como el HPV-45 y -58 y los casos de infecciones múltiples son frecuentes en mujeres del nordeste argentino, lo que podría constituir un rasgo epidemiológico de importancia regional y ser de utilidad en el futuro en los programas de vacunación.

\section{ACKNOWLEDGMENTS}

The authors gratefully acknowledge Dr. Angélica Teyssié and Dr. María Alejandra Picconi from Instituto Nacional de Microbiología y Enfermedades Infecciosas "ANLIS- Carlos G. Malbrán (Buenos Aires)" for their critical revision of the manuscript. This study was partially supported by a grant from the Secretary for Science and Technology of North-East National University (Argentina)- Project PI-611.

\section{REFERENCES}

1. ASTORI, G.; ARZESE, A.; PIPAN, C. et al. - Characterization of a putative new HPV genomic sequence from a cervical lesion using L1 consensus primers and restriction fragment length polymorphism. Virus Res., 50: 57-63, 1997.

2. ASTORI, G.; BELTRAME, A.; PIPAN, C.; RAPHENON, G. \& BOTTA, G.A. - PCRRFLP-detected human papilloma virus infection in a group of Senegalese women attending an STD clinic and identification of a new HPV-68 subtype. Intervirology, 42: 221-227, 1999.

3. BERNARD, H.U.; CHAN, S.Y.; MANNOS, M.M. et al. - Identification and assessment of known and novel human papillomaviruses by PCR amplification, restriction fragment length polymorphism, nucleotide sequence, and phylogenetic algorithms. J. infect. Dis., 170: 1007-1085, 1994.

4. CHUA, K.L. \& HJERPE, A. - Persistence of human papillomavirus (HPV) infections preceding cervical carcinoma. Cancer, 77: 121-127, 1996.

5. FERNANDEZ-CONTRERAS, M.E.; SARRIA, C.; NIETO, S. \& LAZO, P. Amplification of human genomic sequences by human papillomaviruses universal consensus primers. J. virol. Meth., 87: 171-175, 2000.

6. GIULIANO, A.R.; PAPENFUSS, M.; SCHNEIDER, A.; NOUR, M. \& HATCH, K. Risk factors for high-risk type human papillomavirus infection among MexicanAmerican women. Cancer Epidem. Biomarkers Prev., 8: 615-620, 1999.

7. HUSNJAK, K.; GRCE, M.; MAGDIC, L. \& PAVELIC, K. - Comparison of five different polymerase chain reaction methods for detection of human papillomavirus in cervical cell specimens. J. virol. Meth., 88: 125-134, 2000.

8. HWANG, T. - Detection and typing of human papillomavirus DNA by PCR using consensus primers in various cervical lesions of Korean women. J. Korean med. Sci., 14: 593-599, 1999. 


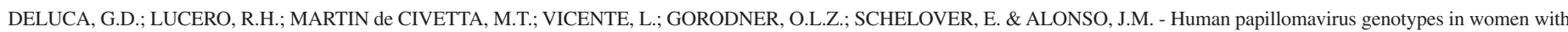
cervical cytological abnormalities from an area with high incidence of cervical cancer. Rev. Inst. Med. trop. S. Paulo, 46(1):9-12, 2004.

9. INTERNATIONAL AGENCY FOR RESEARCH ON CANCER (I.A.R.C). Working Group on the evaluation of carcinogenic risks to humans - Human Papillomaviruses. Lyon, 1995. I.A.R.C. Monographs, 64: 277-282, 1995.

10. KJAER, S.K.; VAN DEN BRULE, A.J.C.; PAULL, G. et. al. - Type specific persistence of high risk human papillomavirus (HPV) as indicator of high grade cervical squamous intraepithelial lesions in young women: population based prospective follow up study. Brit. med. J., 325: 572-576, 2002.

11. KJELLBERG, L.; WANG, Z.; WIKLUND, F. et al. - Sexual behaviour and papillomavirus exposure in cervical intraepithelial neoplasia: a population-based case-control study. J. gen. Virol., 80: 391-398, 1999.

12. KOOPMAN, L.A.; SZUHAI, K.; VAN EENDENBURG, J.D. et al. - Recurrent integration of human papillomaviruses 16, 45, and 67 near translocation breackpoints in new cervical cancer cell lines. Cancer Res., 59: 5615-5624, 1999.

13. MANOS, M.M.; KINNEY W.K.; HURLEY L.B. et al. - Identifying women with cervical neoplasia: using human papillomavirus DNA testing for equivocal Papanicolaou results. J. Amer. med. Ass., 281: 1605-1610, 1999.

14. MARKERT-HAHN, C.; BERDING, C. \& KUHN, C. - Critical level and detection limit: performance measures for PCR-based assays. J. virol. Meth., 74: 139-148, 1998.

15. MATOS, E.L. \& LORIA, D. - Epidemiología del cáncer. Ciencia Hoy, 13: 24-29, 2003.

16. MUÑOZ, N.; BOSCH, X.; SANJOSÉ S. et al. - Epidemiologic classification of human papillomavirus types associated with cervical cancer. New Engl. J. Med., 348: 518$527,2003$.

17. MUÑOZ, N. - Human papillomaviruses and cancer: the epidemiological evidence. J. clin. Virol., 19: 1-5, 2000.

18. NATIONAL INSTITUTES OF HEALTH - Cervical cancer. N.I.H. Consens statement, 14: $1-38,1996$

19. PICCONI, M.; ALONIO, L.V.; GARCIA CARRANCA, A. et al. - Variantes moleculares de virus papiloma humano (HPV) tipos 16 y 18 en adenocarcinomas de cervix. Medicina (B. Aires), 60: 889-894, 2000.

20. PICCONI, M.A.; GRONDA, J.; ALONIO, L.V. et al. - Human papilloma virus in Quechua women from Jujuy, with high frequency of cervical cancer: viral types and HPV-16 variants. Medicina (B. Aires), 62: 209-220, 2002.
21. PONTEN, J. \& GUO, Z. - Precancer of the human cervix. Cancer Surv., 32: 201-229, 1998.

22. RATNAM, S.; FRANCO, E.L. \& FERENCZY, A. - Human papillomavirus testing for primary screening of cervical cancer precursors. Cancer Epidem. Biomarkers Prev., 9: 945-951, 2000.

23. REGUERA, M.; SAN MIGUEL, P.; GOMEZ, C. et al. - Correlación diagnóstica entre las displasias de cérvix y detección por PCR del papiloma virus humano. In: IVCVHAP, 2001 POSTER-E-026 (05/02/2001). Available at http://conganat.uninet.edu/ Comunicación-E/026/.

24. SASAGAWA, T.; BASHA, W.; YAMAZAKI, H. \& INOUE, M. - High-risk and multiple human papillomavirus infections associated with cervical abnormalities in Japanese women. Cancer Epidem. Biomarkers Prev., 10: 45-52, 2001.

25. SCOTT, D.R.; HAGMAR, B.; MADDOX, P. et al. - Use of human papillomavirus DNA testing to compare equivocal cervical cytologic interpretations in the United States, Scandinavia, and the United Kingdom. Cancer, 96: 14-20, 2002.

26. SCHIFFMAN, M.H.; BAUER, H.; HOOVER, R. et al. - Epidemiologic evidence showing that human papillomavirus infection causes most cervical intraepithelial neoplasia. J. nat. Cancer Inst., 85: 958-964, 1993.

27. SLATTERY, M.; OVERALL Jr., J.C.; ABBOTT, T.M. et al. - Sexual activity, contraception, genital infections, and cervical cancer: support for a sexually transmitted disease hypothesis. Amer. J. Epidem., 130: 248-258, 1989.

28. STERN, P.L.; BROWN, M.; TACEY, S. N. et al. - Natural HPV immunity and vaccination strategies. J. clin. Virol., 19: 57-66, 2000.

29. TANG, W.K. - Oncogenic human papillomavirus infection: epidemiology in local highrisk women. Hong Kong Derm. Venearol. Bull., 10:160-163, 2002.

30. TONON, S.A.; PICCONI, M.A.; ZINOVICH, J.B. et al. - Human papillomavirus cervical infection and associated risk factors in a region of Argentina with a high incidence of cervical carcinoma. Infect. Dis. Obstet. Gynecol., 7: 237-243, 1999.

31. VILLA, L.L. - Human papillomaviruses and cervical cancer. Advanc. Cancer Res., 65: 321-341, 1997.

Received: 4 July 2003

Accepted: 19 November 2003 